\title{
Lord Lugard
}

Among those who have written tributes to the memory of the Institute's late Chairman none, perhaps, is more qualified than Mr. R. Nicholson, C.M.G., who joined his staff as Private Secretary in 1900 and was in closest association with him after his retirement until the end. In an all-too-short article in African Affairs for January 1946, Mr. Nicholson dwells chiefly upon two features of his great chief's character: his almost superhuman power of industrious concentration and his utter selflessness-' never a thought for himself but only for the backward peoples whose interests he had made his own'. When he was over eighty, two African experts came for the night to Little Parkhurst. With a brief interval for dinner their discussion went on from tea-time to midnight. As the visitors rose to go to bed, Lugard said to one of them: ' There is one important subject I want to talk over with you.' The other threw up his hands. 'I'm utterly exhausted,' he exclaimed, 'I simply must go to bed.' After he had gone Lugard said: 'I'm rather glad he went, because I can now draft my speech for the House of Lords to-morrow'; and at midnight he settled down for a couple of hours' solid work. Mr. Nicholson concludes with these words: 'At the foot of the memorial brass in Abinger Church are some words once used by him which his wife, before she died, asked might be inscribed there when he followed her:

"All I did was to try to lay my bricks straight."

He was the last of the long line of great empire-builders, and the noble humility of the epitaph was typical of the spirit which inspired his life-work.'

\section{Research in the Gambia}

THE Government of the Gambia has published the report submitted by the Director of the Institute, Professor Daryll Forde, on the preliminary survey which he made in May i945 for the purpose of ascertaining what sociological research was necessary in the territory. Notes on the ethnic groups are given in an appendix: the Mandingka, Wolof, Serahuli, the Fulbe (Firdu, Jombo, Lorobo, Habobo, Hamanabi, Torodo, Jawando, Labo and Futo), the Jola, and minor groups. A survey reveals two outstanding facts: (I) the great extent of ethnic intermixture; this was accentuated by the upheavals during the Muslim wars in the nineteenth century and is continuing at the present time. There is little overt hostility between the groups; but the diversity is adverse to social cohesion. (2) Over much of the territory warrior bands imposed themselves during the Muslim wars on these mixed populations and established new chiefdoms, of which the officially recognized chieftainships of the present day are often direct continuations. These circumstances probably account in large measure for the weak development of a sense of unity and of community of interest. Professor Forde got the impression that in many villages the ties between the people and the chieftainship are not infrequently feeble or of an unsatisfactory character. In other places, where there was a substantially homogeneous population and a Chief of local lineage, a strong social cohesion was apparent. Where there is a lack of cultural homogeneity it is difficult to secure a general response to efforts by Government and others to promote political and economic advance. Professor Forde's conclusions include proposals for an investigation of this subject so that the results may be made available to administrative and other officials. If a policy of reorganizing native courts and of creating councils is to be pursued the ethnic character and social structure of each area should be reviewed and also the present position of the seyfuship in the eyes of the people and of the chief himself should be clearly ascertained. A comprehensive review of the chiefdoms is suggested, including inquiry into the wider allegiances that were formerly owed and still may be significant in certain cases, and into the genealogies of the chiefly lines. Professor Forde 